\title{
REKOMENDASI DESIGN ANALISIS KREDIT MIKRO MELALUI EVALUASI PENYEBAB KEBANGKRUTAN DAN KESALAHAN PENDEKATAN DEBITUR
}

\author{
Bambang Wahyudiono \\ Dosen Tetap Fakultas Ekonomi Universitas Pakuan
}

\begin{abstract}
ABSTRAK
Debitur mikro atau yang terkategorikan dalam Usaha Mikro dan Kecil (UKM) memiliki karakteristik yang unik dan berbeda dengan kondisi debitur korporasi yang memiliki berbagai instrumen untuk mudah dikenali dan dievaluasi. Keunikan usaha mikro belum sepenuhnya dapat dipotret dan dianalisa secara memadai sehingga hasil analisis yang dilakukan pun berpotensi keliru. Kekeliruan ini berdampak pada kredit bermasalah dengan NPL sebagai indikator utama. Kredit UKM bermasalah salah satu buktinya adalah kondisi kebangkrutan. Bangkrut merupakan puncak masalah dari kredit bermasalah. Penyelesaian yang dilakukan pun harus metode penyelesaian bukan perbaikan. Jalan yang ditempuh adalah phase out strategy yaitu dengan menjual jaminan yang ada karena usaha yang merupakan jaminan utama kredit sudah tidak ada lagi. Kondisi bangkrut, dalam penelitian ini, dilakukan melalui evaluasi sebab atau faktor penyebab. Bangkrut disebabkan UKM tidak layak tapi dinilai layak, karena kesalahan analisis yang dilakuan. Melalui penelitian ini, direkomendasikan bagaimana mendesign anaisis kredit mikro secara lebih komprehensif sehingga kredit bermasalah dalam bentuk kebangkrutan dapat diminimalkan. Kredit yang menyebabkan UKM bangkrut bukan saja merugikan lembaga keuangan yang telah memberi kredit namun juga bentuk kontra produktif pembinaan UKM. UKM adalah unik, oleh sebab itu tidak semua jenis kredit berdampak positif terhadap pengembangan UKM. Pemberdayaan UKM akan lebih efektif jika dilakukan melalui seleksi jenis kredit yang boleh ditawarkan. Interaksi Lembaga keungan dan UKM tanpa batasan kebijakan sangat rawan bermasalah bagi UKM. Ada kondisi asimetri informasi bagi UKM namun hal ini terkadang dimanfaatkan lembaga keuangan untuk mendapatkan keuntungan bahkan dari jaminan yang disodorkan ke lembaga keuangan.
\end{abstract}

Kata kunci: Usaha Mikro Kecil, analisa kredit, over financing, tingkat suku bunga, uji coba usaha, gagal ekspansi, tata kelola, kepemimpinan, kebangkrutan, kemampuan membayar, strategi penyelesaian.

\begin{abstract}
Micro entrepreur that commons calls as small medium entreprise have unique characteristics. This is difference to type of corporations with all instrument embeded that can be evaluated. Accuracy of their instruments and documented information, enable to analyze more valid. This is differ whith micro business. Unpredictable their condition will impact to poor result analysis done by financial institutions. Non performing loan or NPL is main indicator that show credit or loan problems. Banckruptcy is the worst conditions when micro credit on NPL categories. In this research, we try to identify some factor above for improvement design or process of analysis micro credit. Micro business banckruptcy conditions not only unproper approach for financial institution but also unappropriate empowerment for micro business.
\end{abstract}

Key words: Small business scale, credit analysis, over financing, interest rate, trial business, unsucced expansion, management, leadership, banckruptcy, repayment capacity, phase out strategy.

\section{Pendahuluan}

Pemilihan Usaha Mikro Kecil dalam proses analisis kredit yang biasanya tertuang dalam kebijakan kredit masih selalu berusaha untuk mendapatkan metode terbaik. Upayaupaya yang dilakukan tersebut tidak terlepas dari realisasi kredit bermasalah yang terus terjadi dengan berbagai kondisi dan alasannya. Kredit bermasalah pada skala yang tidak tertolong lagi, memenuhi kriteria usaha telah bangkrut. Penyebab kebangkrutan usaha mikro kecil sangat komplek, diantara penyebab yang ingin dievaluasi dalam penelitia ini adalah sejauh mana 
dampak pemberian kredit yang berakibat kontra produktif pada keberlangsungan usaha.

Program pelatihan kepada staf atau SDM lembaga keuangan terus dilakukan. Bahkan ada kebijakan bank Indonesia yang kemudian menjadi rujukan lembaga keuangan bukan bank mengharuskan adanya anggaran training and development sebesar $10 \%$ dari total anggaran perusahaan. Kebijakan ini tentu saja ditujukan untuk meningkatkan kompetensi dan skill SDM sehingga tidak salah memberikan kredit kepada calon debitur yang tidak memenuhi kriteria. Tantangan dan keberagaman UKM yang selalu dinamis, menuntut setiap lembaga kredit untuk merelisasikan sehingga tidak terjebak pada kredit yang tidak sehat.

Memilih usaha mikro kecil layak kredit berarti tidak mudah. Ada dua tantangan utama yang dihadapi oleh SDM bank atau lembaga keuangan. Pertama, adalah kemampuan memahami profil UKM yang layak. Kedua, kemampuan membaca UKM di lapangan seperti yang dimaksud dalam kebijakan tertulis. Keduanya menuntut skill yang baik. Meskipun praktek ini menjadi best practice di perbankan komersial, namun untuk memilih segmen pasar mikro kecil juga diperlukan kemampuan ini. Memilih UKM layak sama sulitnya dengan membekali SDM untuk mampu melihat UKM layak. Jadi untuk sektor usaha Mikro kecil, justru memiliki tantangan yang lebih unik.

Proses pemilihan kredit harus benar. Kesalahan proses adalah sesuatu yang fatal. Bisnis keuangan (kredit) berbeda dengan bisnis jenis lain. Dana hanya dapat dicairkan kepada debitur bilamana debitur tersebut sesuai kriteria yang ditentukan. Tidak semua calon debitur UKM memenuhi syarat untuk diberikan kredit. Resiko ini bukan hanya ditujukan untuk tujuan lembaga keuangan yang menjaga keuangannya tetap sehat, namun juga untuk menjadi kepentingan usaha mikro kecil tersebut. Pemberian kredit yang tidak tepat, akan membahayakan usaha Mikro. Usaha mikro yang tidak siap akan tergoda untuk membelanjakan uang tidak pada tujuan produktif atau tidak dalam rangka pengembangan usaha. Usaha Mikro yang tidak siap juga akan cenderung membelanjakan untuk konsumtif atau pola hidup tidak produktif. Kecenderungan ini mengakibatkan uang yang ditermanya tidak akan terbayarkan. Dengan komitmen yang telah diputuskan, pembayaran hutang tidak berasal dari hasil usaha namun dari asset yang ada, sehingga pada akhirnya berujung pada kebangkrutan.

Menurut pasal 1 ayat 11 Undangundang No.10/1998 tentang perubaha Undang-undang No.7/1992 tentang perbankan, kredit adalah penyediaan uang atau tagihan yang dapat disamakan dengan itu, berdasarkan persetujuan atau kesepakatan pinjam meminjam antara bank dengan pihak lain yang mewajibkan pihak peminjam untuk melunasi utangnya setelah jangka waktu tertentu dengan pemberian bunga.

Tujuan kredit dapat dilihat dari sisi bank maupun debitur. Kedua tujuan ini saling berhubungan dan saling mempengaruhi. Bagi bank atau lembaga keuangan, tujuan kredit tentunya adalah dalam rangka untuk mencari keuntungan. Hasil dari pemberian kredit dapat berbentuk bungan dan biaya administrasi yang merupakan balas jasa yang dibebankan kepada nasabah. Keuntungan utama yang diperoleh adalah bersumber dari bunga (margin/bagi hasil) dari kredit/pembiayaan yang diberikan.

Dari sudut usaha mikro kecil atau debitur adalah dalam rangka untuk membantu usahanya baik berbentuk dana investasi maupun dana modal kerja. 
Dengan bantuan dana tersebut, usaha mikro kecil akan mampu memperluas usahanya.

Kedua tujuan tersebut dapat dicapai apabila proses seleksi atau pemilihan kredit yang dilakukannya adalah benar. Setidaknya secara tradisional ada beberapa prinsip yang menjadi acuan bank dan lembaga keuangan dalam proses seleksi kredit, yaitu 5C dan 7P.

Prinsip 5C adalah Character (keyakinan bahwa watak atau sifat calon debitur benar-benar dapat dipercaya), Capacity (kepastian akan kemampuan nasabah untuk dapat mengembalikan dana yang dipinjamnya), Capital (kepastian penggunaan modal secara efektif), Collateral (Jaminan yang dapat diberikan calon debitur) dan Condition (prospek perekonomian dan politik termasuk kondisi dan prospek usaha debitur yang dijalankan). Sedangkan $7 \mathrm{P}$ meliputi Personality (kepribadian dan tingkah laku sehari-hari), Party (mengelompokkan nasabah dalam kelompok-kelompok tertentu), Purpose (tujuan nasabah dalam mengambil kredit), Prospect (menilai apakah usaha nasabah di masa yang akan datang menguntungkan atau tidak), Payment (cara dan darimana nasabah mengembalikan kredit), Profitability (analisis kemampuan nasabah mendapatkan profit dan bagaimana trend atau kecenderungannya) dan Protection (bagaimana menjaga kredit agar benarbenar dapat tertagih).

Seleksi atau pemilihan calon debitur dikatakan efektif jika prinsip atau kriteria di atas kesemuanya prosesnya dilakukan secara benar dan substansi yang dinilai adalah kondisi apa adanya di lapangan. Selain itu tidak terjadi kesalahan menangkap informasi dan tidak terjadi kesengajaan merekayasa informasi.

Kualitas seleksi proses kredit sangat ditentukan oleh kualitas dan integritas SDM, oleh sebab itu SDM perbankan termasuk lembaga keuangan semestinya diperlakukan sebagai asset yang paling berharga. SDM menjadi penentu apakah asset utama perbankan kelak di kemudian hari menjadi tumbuh dan berkembang atau justru sebaliknya.

Meskipun kriteria dan proses seleksi calon debitur telah dibakukan dalam berbagai kebijakan dan SOP (Standar Prosedeur Operasi), namun dalam pelaksanaannya banyak kredit yang tidak efektif. Kredit telah bermasalah, dalam arti menjadi Non Performing Loan bagi bagi bank karena debitur tidak mampu membayar. Bahkan, kondisi debitur menjadi bangkrut.

Salah satu lembaga pembiayaan non bank cabang Bandung yang menjadi obyek penelitian memiliki portofolio sebagai berikut:

Tabel 1. Manajemen Portofolio Pembiayaan UKM Bulan Desember 2014

Table1. SME Financing Portfolio Management Month December 2014

\begin{tabular}{|l|r|r|r|}
\hline \multicolumn{1}{|c|}{ KETERANGAN } & \multicolumn{1}{c|}{ TOTAL } & \multicolumn{1}{c|}{ KLASTER I } & \multicolumn{1}{c|}{ KLASTER II } \\
\hline Target Bulan ini: & & & \\
\hline Pencairan net & 6.036 .000 .000 & 3.270 .000 .000 & 2.766 .000 .000 \\
\hline Run off & & & \\
\hline Outstanding & 79.914 .587 .420 & 38.300 .293 .814 & 41.614 .293 .606 \\
\hline PAR-Outstanding & 22.366 .477 .020 & 11.273 .134 .164 & 11.093 .342 .856 \\
\hline
\end{tabular}




\begin{tabular}{|l|r|r|r|}
\hline PAR-\% & $27,99 \%$ & $29.43 \%$ & $26.66 \%$ \\
\hline NPL - Outstanding & 4.393 .343 .491 & 2.650 .431 .831 & 1.742 .911 .660 \\
\hline NPL - \% & $5.5 \%$ & $6.92 \%$ & $4.19 \%$ \\
\hline & & & \\
\hline
\end{tabular}

Sumber: Diolah peneliti

Kantor Cabang memiliki 2 (dua) area bisnis yang disebut dengan Klaster. Klaster terdiri dari beberapa outlet yang melakukan pembiayaan secara langsung kepada UKM. Kredit bermasalah dalam bentuk UKM Bangkrut terdapat dalam golongan NPL atau Non Performing Loan. Dalama prakteknya meskipu suatu UKM sudah bangkrut namun belum segera dihapus dari daftar outstanding pembiayaan. Penghapusan atau WO memerlukan birokrasi persetujuan yang tidak hanya bisa dilakukan di kantor cabang. Mengingat proses panjang dan cabang harus segera mencari penggantinya, maka meskipun kondisi bangkrut tidak otomatis dapat dihapus dari dari outstanding. Dari total outstanding Rp.79,9 miliar terdapat debitur NPL Rp.4,4 miliar diantaranya terdapat 54 (lima puluh empat) debitur bangkrut. Namun di antara debitur bangkrut tersebut sudah tidak ada di daftar outstanding karena sudah dilakukan WO (Write off) atau hapus buku. Debitur WO hanya bisa diketahui dari observasi lapangan.

Tabel 2. Pengendalian NPL Pembiayaan UKM Bulan Desember 2014

Table 2. Control Financing SME NPL Month December 2014

\begin{tabular}{|l|r|r|r|}
\hline \multicolumn{1}{|c|}{ KETERANGAN } & \multicolumn{1}{c|}{ TOTAL } & \multicolumn{1}{c|}{ KLASTER I } & \multicolumn{1}{c|}{ KLASTER II } \\
\hline Posisi NPL November & 4.393 .343 .491 & 2.650 .431 .831 & 1.742 .911 .660 \\
\hline Skema Penurunan NPL & & & 0 \\
\hline Restrukturisasi (3R) & 85.703 .668 & 85.703 .668 & 0 \\
\hline Cash collection & 322.153 .250 & 42.295 .150 & 279.858 .100 \\
\hline Phase out & 238.382 .175 & 287.600 & 238.094 .575 \\
\hline Klain Asuransi & 0 & 0 & 0 \\
\hline Write Off & 0 & 0 & 517.952 .675 \\
\hline Total Penurunan NPL & 646.239 .093 & 128.286 .418 & 1.454 .658 .985 \\
\hline Prediksi NPL Desember & 4.298 .895 .598 & 2.844 .236 .613 & \\
\hline & & & \\
\hline
\end{tabular}

Sumber: Diolah peneliti

Terdapat 2 (dua) skema penanganan pembiayaan bermasalah yaitu stay strategy (penyelamatan) dan Phase out strategy (penyelesaian). Skema penyelamatan meliputi 3R (Rescheduling, Reconditioning, Restructuring). Upaya penyelesaian (phase out) dilakukan melalui pengadilan dan di luar pengadilan. Diantaranya adalah collection, penjualan jaminan sukarela, lelang, eksekusi HT, perdata dan bahkan pidana.

Penanganan debitur bangkrut semestinya masuk dalam kategori phase out atau penyelesaian dan akhirnya harus dilakukan write off.

Dari jumlah debitur atau UKM yang NPL (Rp.4.4 miliar) tersebut 7 diantaranya telah bangkrut atau usaha tutup. Tidak semuanya menjadi bagian dari Rp.646 juta dalam bentuk 3R, cash 
collection dan phase out. Pendekatan lembaga keuangan adalah mempertahankan suatu debitur meskipun usaha sudah bangkrut namun masih ada pembayaran meskipun sumber dana tidak berasal dari usaha yang dibiayai. Obeservasi debitur bangkrut tidak bisa dilihat dari dokumentasi yang ada, tetapi harus melakukan cek fisik dan pengamatan langsung di tempat usaha dan tempat tinggal pengusaha UKM.

Dari keseluruhan NPL NOA (Number of Account) sebesar 5,5\%, terdapat 7 debitur bangkrut. Keseluruhan UKM bangkrut tersebut dinilai dari segi dokumentasi proses sudah lengkap dan memadai. Kelengkapan yang tampak dalam proses tertulis ini juga ditunjukkan adanya persetujuan kredit oleh komite kredit. Semua komite memberikan persetujuan, sehingga kredit dapat dicairkan kepada debitur UKM. Namun pada saat diteliti kesemuanya sudah bangkrut. Bidang usahanya adalah toko kelontong, agen beras, usaha salon, perajin mebel, usaha kredit barang, pabrik roti, jual beli ikan konsumsi.

Berangkat dari fenomena di atas, peneliti merasa bahwa lembaga keuangan yang menjadi obyek penelitian ini perlu melakukan kajian ulang terhadap kebijakannya yang berdampak pemilihan UKM yang akan dibiayai dengan tidak semata-mata mencari keuntungan atau mengejar target oustanding dan pencairan kredit sebagai motivasi utama. Kebijakan untuk mengejar target diluar kapasitas telah mengarahkan SDM menjadi tidak melakukan proses secara profesional dan cenderung mengabaikan integritas. Kesalahan ini telah mengakibatkan 7 dari 300 NOA telah bangkrut. Oleh karena itu peneliti tertarik untuk melakukan penelitian lebih lanjut dengan judul: Rekomendasi Pemilihan Usaha Mikro Kecil (UKM) Layak Kredit Melalui Evaluasi Kebangkrutan dan
Karakteristik Debitur (Studi kasus penyaluran kredit Lembaga Keuangan).

Penelitian ini akan fokus pada pembahasan sebab-sebab UKM bangkrut karena substansi pemberian kredit. Kredit bisa bersifat produktif namun sebaliknya juga kontra produktif. Kredit menjadi kontraproduktif dan dapat berujung pada kebangkuran UKM setelah melalui masa Non Performing Loan atau kredit bermasalah. Penelitian akan melihat sejauh mana peran dari beberapa faktor yang ditemukan di lapangan berperan penting dalam proses kebangkrutan.

Penelitian ini bertujuan:

1. Mengetahui keterkaitan antara kebangkrutan usaha milik UKM (Usaha Mikro Kecil) yang disebabkan oleh kredit.

2. Menganalisis pemilihan awal proses kredit melalui identifikasi karakteristik debitur UKM dan penanganannya paska pencairan kredit.

3. Pemetaan adanya potensi asimetri informasi proses kredit dari sudut UKM dan lembaga keuangan.

\section{Landasan Teori \\ 2.1. Kebangkrutan dan Kredit Bermasalah}

Dampak dari suatu hutang adalah peluang bangkrut. Karena hutang misalnya yang berasal dari kredit lembaga keuangan memiliki sisi buruk apalagi jika hutang tersebut tidak termanage dengan baik.

Salah satu keburukan (utama) dari hutang adalah meningkatnya beban biaya bunga, sehingga meningkatkan peluang bangkrut.

Stphen A.Ross dalam Corporate Finance mengatakan bahwa "An involuntary banckruptcy petition may 
filed by creditors if both the following conditions are met:

1. The corporation is not paying debts as the become due.

2. If there are more than 12 creditors, at least three with claims totaling \$13,475 or more must joint the filing. If there are fewer than 12 creditors, then only one with a claim of $\$ 13,475$ is required to file."

Many potential lenders use credit scoring models to asses the creditworthiness of prospective borrowers. The general idea is to find factors that enable the lenders to discriminate between good and bad credit risks. To put it more precisely, lenders wants to identify attributes of the borrower that cans. be used to predict default or bankcruptcy.

Alat ukur yang digunakan untuk mengukur tingkat kebangkrutan suatu perusahaan biasanya adalah Z-Skor dari Edward Altman.

Edward Altman, a professor at New York University, has developed a model using financial statement ratios and multiple discriminant analysis to predict banckruptcy for publicity traded manufacturing firms and also nonmanufacturer.

Model ini dapat pula dijadikan salah satu indikator kinerja perusahaan. Rumus alat ukur ini adalah $\mathrm{Z}=6,56(\mathrm{X} 1)$ $+3,26(\mathrm{X} 2)+1,05(\mathrm{X} 3)+6,72(\mathrm{X} 4) . \mathrm{X} 1=$ Net working capital/Total Asset, $X 2=$ Accumulated retained earnigs/Total assets, X3 = Ebit/Total assets, $X 4=$ Book value of equity/Total liabilities.

Dari ukuran itu yang bisa dibaca adalah sejauh mana suatu perusahaan akan cenderung mengalami bangkrut atau sebaliknya suatu perusahaan aman dari bahaya kebangkrutan. Ukurannya adalah jika $\mathrm{Z}<1,23$ maka indicates a bankruptcy prediction, $1,23 \leq \mathrm{Z} \leq 2,90$ indicates a gray area, $Z>2,90$ indicates no bankcruptcy. Jadi untuk aman dari ancaman bangkrut suatu perusahaan harus memiliki skor Z lebih dari 2,90.

Masalahnya alat ukuran Z Altman di atas sulit untuk diterapkan pada usaha skala UKM Usaha Mikro Kecil, karena belum dimilikinya laporan keuangan baik neraca maupu laporan laba rugi. Tidak tersedianya laporan keuangan tersebut sebagai akibat belum dilakukannya proses administrasi pembukuan berdasarkan prinsip akuntansi yaitu double entry system. UKM sudah mempunyai catatan pembukuan biasanya terkait keluar masuk uang dan yang melalui rekening. Namun belum bisa menyusun laporan keuangan.

Kondisi bangkrut dari UKM antara lain bisa didekati dengan perhitungan cash flow dan persediaan secara fisik serta perhitungan repayment capacity. Perusahaan bangkrut tidak memiliki cash flow, persediaan tidak ada atau yang rusak. Cash flow yang buruk menjadikannya tidak memiliki daya bayar.

Penyebab bangkrut dimulai dari kredit bermasalah. UKM bangkrut dapat dipastikan merupakan bagian dari kredit bermasalah. Menurut Veithzal Rival, ada beberapa pengertian kredit bermasalah:
1. Kredit yang di dalam pelaksanaannya belum mencapai/memenuhi target yang diinginkan oleh pihak bank.

2. Kredit yang memiliki kemungkinan timbulnya risiko di kemudian hari bagi bank dalam arti luas.

3. Mengalami kesulitan di dalam penyelesaian kewajibankewajibannya baik dalam bentuk pembayaran kembali pokoknya 
dan/atau pembayaran bunga, denda, keterlambatan serta ongkosongkos bank yang menjadi beban debitur yang bersangkutan.

4. Kredit dimana pembayaran kembalinya dalam bahaya, terutama apabila sumber-sumber pembayaran kembali yang diharapkan diperkirakan tidak cukup untuk membayar kembali kredit, sehingga belum mencapai/memenuhi target yang diinginkan oleh bank.

5. Kredit dimana terjadi cedera janji dalam pembayaran kembali sesuai perjanjian, sehingga terdapat tunggakan, atau ada potensi kerugian di perusahaan debitur sehingga memiliki kemungkinan timbulnya risiko di kemudian hari bagi bank dalam arti luas.

6. Mengalami kesulitan di dalam penyelesaian kewajibankewajibannya terhadap bank, baik dalam bentuk pembayaran kembali pokoknya, pembayaran bunga, pembayaran ongkos-ongkos bank yang menjadi beban nasabah/debitur yang bersangkutan.

7. Kredit golongan perhatian khusus, kurang lancar, diragukan dan macet serta golongan lancar yang berpotensi menunggak.

Inti persoalan dari kredit bermasalah - NPL (Non Performing Loan) - adalah kondisi dimana kualitas kredit atau pembiayaan mengalami penurunan kolektibilitas menjadi kurang lancar, diragukan dan macet sehingga diperlukan upaya untuk penyelematan atau penyelesaian terhadap pembiayaan bermasalah tersebut.

Kategori pembiayaan bermasalah atau NPL ada 3 yaitu:
1. Kurang Lancar (Kolektibilitas 3): dengan aging tunggakan $90<\mathrm{KL}$ $\leq 180$ hari (s/d 6 bulan)

2. Diragukan (kolektibilitas 4): dengan aging tunggakan $180<\mathrm{D} \leq$ 270 hari ( 6 bln s/d 9 bulan)

3. Macet (kolektibilitas 5): dengan aging tunggakan $>270$ hari (9 bulan ke atas)

Paling kurang terdapat 6 (enam) sinyalemen kredit atau pembiayaan akan bermasalah, yaitu:

1. Penyaluran pembiayaan tidak sesuai dengan covenant : penyipangan tujuan penggunaan pembiayaan (side streaming), meminjam nama orang lain, penggunaan bersama, dana digunakan untuk membayar hutang ke pihak lain.

2. Data/informasi yang disampaikan saat pemberian pembiayaan palsu/tidak benar: identifikasi palsu, tanda tangan palsu, alamat rumah palsu, data keuangan fiktif baik sumber pembiayaan maupun data kekayaan.

3. Agunan/jaminan bermasalah: Fisik dan/atau lokasi jaminan berbeda dengan dokumen jaminan, dokumen jaminan palsu, jaminan milik orang lain yang dijanjikan diberi fee, fisik agunan sudah dipindahtangankan.

4. Alasan klasik: memberikan alasan yang kuat: sakit, daftar sekolah, kematian, melahirkan, kebutuhan hari raya; dipinjamkan ke orang lain yang kemudian macet, tergiur trend/gaya hidup; mengajukan penggantian agunan dari milik pribadi ke milik orang lain.

5. Sebab yang kuat: usaha gagal, barang tidak laku, mengalami kerugian (biaya membengkak, pendapatan turun, modal habis), korban penipuan. 
6. Kelemahan internal: kurang tajamnya analisa, kurang informasi, monitoring kurang, karyawan nakal.

\subsection{Repayment Capacity Kredit Mikro}

Repayment capacity adalah proses perhitungan untuk menentukan berapa cash flow bebas yang dimiliki debitur dibandingkan dengan angsuran pinjaman yang akan dibebankan karena pemberian kredit. Biasanya RC dianggap dalam level mampu atau sanggup menunaikan kewajiban jika besarnya angsuran tidak melebihi sepertiga dari penghasilan bersihnya. Atau, jika dalam prosentase biasanya best practice nya adalah $31 \%$ s/d 35\%.

Secara bertahap perhitungan RC untuk kredit kepada sektor mikro kecil adalah sebagai berikut:

Pendapatan usaha atau omset per bulan (a)

Harga pokok penjualan (b)

Biaya usaha (c)

Keuntungan Usaha $(d)=a-b-c$

Penghasilan dari usaha lainnya (e)

Penghasilan gaji (f)

Total penghasilan $(\mathrm{g})=\mathrm{d}+\mathrm{e}+\mathrm{f}$

Total biaya rumah tangga $(\mathrm{h})$

Sisa penghasilan $(\mathrm{i})=\mathrm{g}-\mathrm{h}$

Angsuran pinjaman saat ini (j)

Penghasilan bersih $(\mathrm{k})=\mathrm{i}-\mathrm{j}$

Angsuran pinjaman baru (l)

Rasio Repaymen Capacity $9 \mathrm{~m})=(\mathrm{l}) /(\mathrm{k})$
Secara jelas dari yang tampak dalam komponen perhitungan RC di atas adalah cukup terbukanya peluang salah mengambil informasi dari pengusaha UKM. Risiko kesalahan yang cukup tinggi ini disebabkan UKM tidak cukup memiliki bukti tertulis dan otentik yang menunjukkan kondisi usaha dan kapasitas yang sebenarnya. Peluang ini bisa terbuka dan menjadi kesalahan pada saat SDM Lembaga Keuangan mengajukan kepada komite kredit untuk mendapat persetujuan.

Peluang yang bisa berisiko salah antara lain pendapatan usaha, harga pokok penjualan, biaya usaha, penghasilan dari usaha lainnya, penghasilan gaji, biaya rumah tangga. Ketidakakuratan dalam menentukan nominal komponen tersebut berarti membiayai atau memberikan kredit kepada usaha yang tidak layak namun dianggap layak. Dampak akhir dari kesalahan perhitungan tersebut adalah kebangkrutan usaha. Debitur yang tidak mempunyai kemampuan bayar karena memang omset rendah, biaya tinggi atau terlalu banyak hutang namun dianggap sebagai UKM potensiall dengan indikator RC yang baik atau RC yang memenuhi ketentuan.

\subsection{Pendekatan Karakteristik Debitur \\ Penanganan pembiayaan}

bermasalah berdasarkan karakteristik debitur dapat digambarkan dalam grafik sebagai 


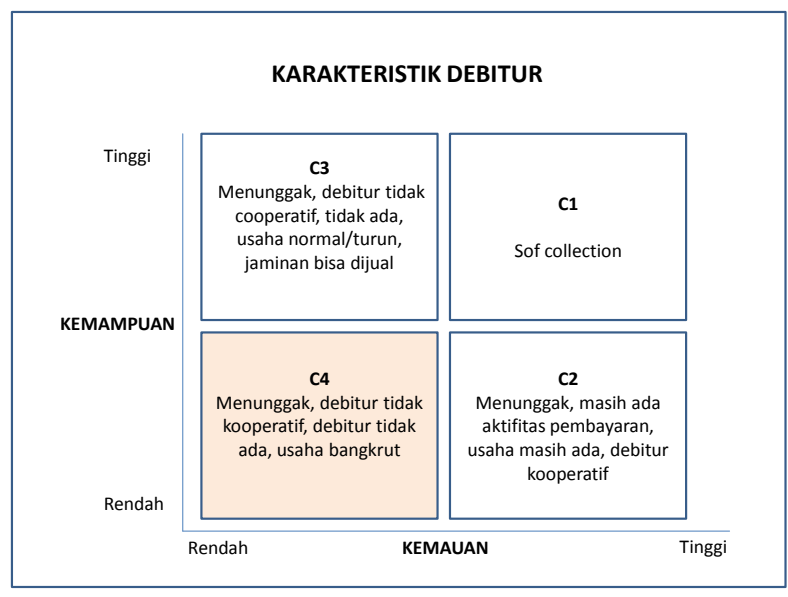

Debitur bangkrut terkategorikan dalam kolom $\mathrm{C} 4$, yaitu memiliki kemauan membayar yang rendah dan juga kemampuan yang rendah. Hal ini disebabkan karena debitur kondisi usahanya sudah ada atau bangkrut. Tidak ada kemauan membayar karena memang sudah ada, sehingga kebanyakan debitur dengan karakteristik ini sudah hilang atau tidak ada lagi. Debitur dengan karakteristik ini akhirnya dianggap tidak kooperatif karena memang tidak ada kemampuan lagi untuk membayar atau memenuhi kewajibannya. Kerugian Lembaga keuangan masih dapat terselamatkan jika debitur tersebut memberikan jaminan dan kondisinya dapat dijual. Permasalahan akan semakin rumit jika debitur tidak memberikan jaminan asset fisik dan kondisinya sengketa bahkan palsu. Dalam kondisi demikian, maka praktek knowing your customer benar-benar telah terabaikan.

Pada awal proses kredit dilakukan, semestinya SDM lembaga keuangan mampu mengidentifikasi dalam golongan yang manakah debitur tersebut berada. Lain golongan karakteristik akan berbeda dalam proses selanjutnya baik pendekatan saat bermasalah maupun penyelesaian selanjutnya.

Upaya yang harus dilakukan jika dalam kategori $\mathrm{C} 1$ adalah soft collection karena kondisi debitur adalah memiliki kemampuan dan kemauan yang tinggi. Untuk C2 (kemauan tinggi namun kemampuan rendah) dapat dilakukan restukturisasi. C3 (baik kemampuan maupun kemauan rendah) dengan cara penyelesaian credit (phase out). $\mathrm{C} 4$ juga phase out.

Menganalisis debitur bangkrut dapat teridentifikasi dari proses pembiayaan yang tidak prudent dan tidak mampunya mengenali tipe-tipe debitur. Tipe debitur tertentu akan efektif apabila didekati dengan strategi tertentu. Kesalahan treatment akan mengakibatkan debitur bangkrut. Baik karena karakter buruk maupun memang kapasitas yang sudah menurun drastis. Karakter buruk karena kemauan membayar yang rendah (willingness to pay). Kapasitas dalam arti capacity to pay yang sudah tidak ada. Kedua hal ini semestinya bisa dilihat di awal proses kredit maupun paska pencairan kredit (maintenance). Karakter debitur dapat digambarkan sebagai berikut: 
Tabel 3. Tipe dan Sifat Debtur serta Treatment

Table 3. The Type and Nature of The Debtor and Treatment

\begin{tabular}{|l|l|l|}
\hline \multicolumn{1}{|c|}{ TIPE } & \multicolumn{1}{|c|}{ SIFAT } & \multicolumn{1}{|c|}{ TREATMENT } \\
\hline Dominance & $\begin{array}{l}\text { Orientasi: hasil, tidak sabar, pembuat } \\
\text { keputusan, langsung, percaya diri } \\
\text { tinggi. }\end{array}$ & $\begin{array}{l}\text { Langsung (to the point), Fokus } \\
\text { pada hasil: kapan dan berapa? }\end{array}$ \\
\hline Influence & $\begin{array}{l}\text { Orientasi: manusia, } \\
\text { ramah/bersahabat, terbuka, } \\
\text { emosional }\end{array}$ & $\begin{array}{l}\text { Tidak bicara rincian, bergaul } \\
\text { dekat, follow up terus. }\end{array}$ \\
\hline Steadiness & Orientasi harmoni (kerjasama), tulus, pendengar yang baik. & $\begin{array}{l}\text { Pelan-pelan dan buat gampang, } \\
\text { jawab semua pertanyaan, } \\
\text { yakinkan berulang2, dapatkan } \\
\text { keyakinan mereka }\end{array}$ \\
\hline Compliance & $\begin{array}{l}\text { Orientasi kwalitas, suka baca, taat } \\
\text { aturan, analitis, target, hati-hati }\end{array}$ & $\begin{array}{l}\text { Persiapan matang, terstruktur, } \\
\text { detil, siapkan bukti nyata, } \\
\text { tunjukkan kerugian. }\end{array}$ \\
\hline
\end{tabular}

Sumber: Diolah dari berbagai sumber

Kelemahan debitur tipe dominance adalah terlalu banyak alasan, kurang hati-hati dan terlalu mendekte. Sedangkan kebutuhannya adalah wewenang dan kekuasaan serta prestise. Kelemahan debitur tipe influence adalah kontrol waktu, follow up atau tindak lanjuti, kurang obyektif dan takut ditolak kelompok. Sedangkan kebutuhannya adalah bicara, ngobrol, pengakuan serta penerimaan. Kelemahan debitur tipe Steadiness adalah menghindar pengambilan risiko, menghindari konflik, takut kehilangan rasa aman. Sedangkan kebutuhannya adalah penghargaan (apresiasi), keamanan, waktu banyak. Kelemahan debitur tipe compliance adalah kaku, menunda-nunda, terlalu kritis, serba sempurna. Sedangkan kebutuhannya adalah pekerjaan ketepatan tinggi, faktafakta, waktu banyak. Kesalahan memahami dan treatment, akan menyebabkan informasi yang diberikan tidak valid sehingga membahayakan pada waktu pengambilan keputusan kredit. Kesalahan memahami dan treatment juga berdampak sulitnya mengendalikan selama proses kredit dan kesulitan pada saat penangangan kredit bermasalah.

\subsection{Paradigma UKM Layak}

UKM layak pada umumnya distandarkan dengan kemampuan membayar atau repayment capacity. Bank atau sebagai lembaga keuangan sebagai lembaga titipan dana masyarakat, dituntut untuk mengelola dana titipan dengan sebaik-baiknya. Penggunaan dana harus mengikuti kaidah atau norma prudential. Kehilangan dana harus dipertanggungjawabkan dalam bentuk indikator NPL yang harus rendah. Penyaluran kredit harus didasarkan pada kriteria yang dianggap layak. Pemberian kredit kepada calon debitur yang tidak layak adalah pelanggaran prinsip perbankan dan lembaga keuangan. Proses kredit dikatakan benar dan berprinsip prudent jika calon debitur dinilai layak. Kelayakan tentu saja berdasarkan analisa yang dilakukan oleh SDM perbankan atau lembaga keuangan.

Lembaga keuangan yang tidak memiliki SDM dengan skill atau competency cukup baik akan mudah keliru dalam memahami dan 
menentukan UKM layak. Kesalahan lebih diperparah jika SDM juga memiliki integritas yang rendah. SDM yang memiliki kompetensi dan integritas rendah akan mengakibatkan kontra produktif terhadap tujuan kredit untuk misi pemberdayaan UKM. Kondisi SDM yang rendah juga akan semakin dipicu pemburukannya jika target yang diberikan oleh perusahaan untuk menyalurkan kredit diluar kemampuan atau target yang tidak masuk akal.

Pemberian kredit oleh lembaga penyalur kredit yang tidak tepat produk dan metodologinya akan menyebabkan kesulitan bagi UKM dan kebangkrutan. Bangkrutnya UKM juga akan menyebabkan kerugian bagi lembaga penyalur kredit dengan indikator NPL yang semakin meningkat.

\subsection{Kerangka Berpikir}

Kerangka berpikir penelitian adalah dengan menggunakan penelitian kualitatif. Menurut Creswell (1998) dalam Juliansyah (Metodologi Penelitian), menyatakan bahwa penelitian kualitatif sebagai suatu gambaran kompleks, meneliti kata-kata, laporan terinci dari pandangan responden, dan melakukan studi pada situasi yang alami. Penelitian kualitatif merupakan riset yang bersifat deskriptif dan cenderung menggunakan analisis dengan pendekatan induktif. Landasan teori dimanfaatkan sebagai pemandu agar fokus penelitian sesuai dengan fakta di lapangan. Landasan teori juga bermanfaat untuk memberikan gambaran umum tentang latar belakang penelitian dan sebagai bahan pembahasan hasil penelitian. Penelitian ini juga menggunakan pendekatan studi kasus. Tekanan utama dalam studi kasus (Creswell, 1998) adalah mengapa individu melakukan apa yang dia lakukan dan bagaimana tingkah lakunya dalam kondisi dan pengaruhnya terhadap lingkungan.

\section{Metodologi Penelitian}

Penelitian ini dilakukan dengan menggunakan metode analisis Deskriptif Kuantitatif dengan menggunakan statistik parametrik, untuk menganalisis variabel terikat dan variabel bebas dengan hubungan sebab akibat (causal). Variabel bebas meliputi over finance, tingkat bunga atau margin, pengalaman usaha, kemampuan manajemen, kemampuan leadership. Sedangkan variable terikat adalah kebangkrutan.

Tabel 4. Jenis Variabel

Table 4. Variable Types

\begin{tabular}{|l|l|}
\hline \multicolumn{1}{|c|}{ Variabel bebas } & \multicolumn{1}{c|}{ Variabel terikat } \\
\hline \hline X1 = Over finance & \\
\cline { 1 - 1 } X2 = Tingkat bunga atau margin & \\
\cline { 1 - 1 } X3 = Pengalaman usaha & \\
\cline { 1 - 2 } X = Kemampuan manajemen & \\
\cline { 1 - 2 } X5 = Kemampuan leadership & \\
\hline
\end{tabular}

IV. Hasil dan Pembahasan

Dari 7 (tujuh) debitur yang menjadi obyek penelitian, kesemuanya sudah

kabur 
Tabel 5. Matrik Penyebab Kebangkrutan

Table 5. Matrix Cause Bankruptcy

\begin{tabular}{|l|l|l|}
\hline KATEGORI PENYEBAB & \multicolumn{1}{|c|}{ KONDISI 1 } & \multicolumn{1}{c|}{ KONDSI 2 } \\
\hline OVER FINANCE & Tidak Terdeteksi (OF1) & Terdeteksi (OF2) \\
\hline BUNGA (MARGIN) & Komersial (BM1) & Subsidi (BM2) \\
\hline PENGALAMAN USAHA & Uji Coba (PU1) & Gagal Ekspansi (PU2) \\
\hline $\begin{array}{l}\text { KEMAMPUAN } \\
\text { MANAJEMEN }\end{array}$ & Tata Kelola Lemah (KM1) & Tata Kelola Mature (KM2) \\
\hline $\begin{array}{l}\text { KEMAMPUAN } \\
\text { LEADERSHIP }\end{array}$ & Leadership Lemah (KM1) & Leadership Mature (KM2) \\
\hline
\end{tabular}

Tabel 6. Faktor Penyebab Utama Kebangkrutan UKM per Kategori Penyebab Table 6. Factors Leading Cause of Bankruptcy SMEs per Category Cause

\begin{tabular}{|c|l|c|c|c|c|}
\hline No & \multicolumn{1}{|c|}{ FAKTOR PENYEAB } & UMK 1 & UMK 2 & UMK 3 & UMK 4 \\
\hline 1 & Over Finance - Tdk Terdeteksi & 61,54 & 64,29 & 66,67 & 58,33 \\
\hline 2 & Over Finance - Terdeteksi & 38,46 & 35,71 & 33,33 & 41,67 \\
\hline 3 & Interest - Komersial & 53,85 & 57,14 & 40,00 & 50,00 \\
\hline 4 & Interest - Subisidi & 46,15 & 42,86 & 60,00 & 50,00 \\
\hline 5 & Experience - Uji Coba & 46,15 & 57,14 & 46,67 & 66,67 \\
\hline 6 & Experience - Gagal Ekspansi & 53,85 & 42,86 & 53,33 & 33,33 \\
\hline 7 & Managerial - Rendah & 53,85 & 71,43 & 73,33 & 75,00 \\
\hline 8 & Managerial - Matang & 46,15 & 28,57 & 26,67 & 25,00 \\
\hline 9 & Leadership - Rendah & 61,54 & 64,29 & 60,00 & 58,33 \\
\hline 10 & Leadership - Matang & 38,46 & 35,71 & 40,00 & 41,67 \\
\hline
\end{tabular}

Tabel 5 di atas menunjukkan jika pada faktor penyebab 1 dan 2, 3 dan 4, 5 dan 6, 7 dan 8 , serta 9 dan 10 selalu menunjukkan pilihan dengan bobot masing-masing pasangan adalah $100 \%$. Hal ini diukur dari pada saat observasi dan wawancara, jika penyebab kebangkrutan selalu ada di antara kedua komponen pasangan tersebut. Misalnya pada UKM kelompok 1, kondisi UKMnya adalah 61,54 karena over finance tidak terdeteteksi. Sedangkan 38,46 karena over finance yang terdeteksi. Data OF terdeteksi karena memang dalam perhitungan RC terdapat beberapa kredit sebelumnya yang menjadi kewajiban debitur. Sedangkan OF tidak terdeteksi, berdasarkan wawancara dan data lain pada saat debitur bermasalah sehingga diketahui jika debitur tersebut memiliki banyak tunggakan di tempat lain namun tidak disajikan dalam dokumen kredit RC. Tidak tersaji atau terungkapnya informasi kredit sebelumnya dapat disebabkan karena memang tidak terdeteksi dalam laporan SID Bank Indonesia (Sistem Informasi Debitur) atau kemungkinan lain adalah memang SDM lembaga keuangan menyembunyikan informasi tersebut (terkait integritas atau faktor lain misalnya target dsb). Kondisi OF dijumpai dalam UKM kelompok 1, 2 dan 3 namun proporsinya berbeda-beda. 
Pada kelompok 1 di atas, kebangkrutan dalam kondisi karena interest rate yang tinggi dijumpai pada proporsi 53,85 dari UKM bangkrut yang diteliti. UKM bangkrut dengan kondisi interest rate yang rendah (subsidi) berarti kebangkrutannya lebih disebabkan oleh faktor lainya, bisa karena over finance, uji coba/gagal ekspansi atau lembahnya manajerial dan leadership. Pada kelompok 1, faktor karena gagal ekspansi adalah 53,85 sedangkan karena uji coba usaha baru adalah 46,15. Dari ketiga kelompok usaha UKM tersebut, kesemuanya memiliki kelemahan manajerial dan leadership secara dominan. UKM Kelompok 1 terdiri dari Toko kelontong baik di kios pasar maupun di rumah, Agen penjual beras dan toko-toko kue dengan populasi berjumlah 13 UKM atau $24,07 \%$ dari total UKM bangkrut yang disurvey sebesar 54 UKM. UKM Kelompok 2 terdiri dari pedagang palawija atau hasil bumi, pedagang unggas (ayam) dan bebek petelor dan pedagang ikan konsumsi dengan populasi berjumlah 14 UKM atau $25,93 \%$ dari total UKM bangkrut. UKM Kelompok 3 terdiri dari perajin dan pedagang mebel, penjual kayu, pedagang kredit keliling, perajin tahu dengan jumlah UKM 15 atau 27,78\%. UKM Kelompok 4 terdiri dari usaha salon, pedagang rongsok (atau barang bekas) dengan jumlah 12 UKM atau 22,22\% dari total UKM bangkrut.

Kebangkrutan kelompok UKM 1 secara dominan disebabkan oleh tidak terdeteksinya fasilitas pembiayaan atau kredit yang telah diterima oleh UKM sebelum kredit/pembiayaan diberikan oleh lembaga keuangan obyek penelitian. Selain itu, penyebab faktor lain yang dominan adalah tingkat bunga yang non subsidi atau komersial (suku bunga produk non program), UKM gagal melakukan ekspansi usaha, manajerial dan leadership yang lemah. Kebangkrutan kelompok UKM 2 secara dominan disebabkan oleh over finance tidak terdeteksi, kredit komersial, usaha yang sifatnya coba-coba atau UKM yang sedang merintins usaha sehingga pengalaman minim, manajerial dan leadership yang rendah. Kelompok UKM 3 bangkrut secara dominan disebabkan oleh over finance yang tidak terdeteksi, suku bunga subsidi, gagal ekspansi dan manajeral serta leadership yang rendah. Kelompok Usaha 4 bangkrut dengan penyebab dominan adalah over finance tidak terdeteksi, pengenaan suku bunga yang subsidi maupun komersial, uji coba atau rintisan usaha baru serta lemahnya kemampuan tata kelola (manajerial) dan faktor leadership. 
Tabel 7. Ranking Kontribusi Penyebab Utama terhadap Kebangkrutan UKM per Kelompok UKM

Table 7. Ranking Contributions Main Cause of the bankruptcy of SMEs per group of SMEs

\begin{tabular}{|c|l|c|c|c|c|}
\hline \multirow{2}{*}{ No } & \multicolumn{2}{|c|}{ FAKTOR PENYEBAB UTAMA } & \multicolumn{4}{|c|}{ KONTRIBUSI THD KEBANGKRUTAN } \\
\cline { 3 - 6 } & & UMK 1 & UMK 2 & UMK 3 & UMK 4 \\
\hline 1 & Over Finance - Tdk Terdeteksi & 12,31 & 12,86 & 13,33 & 11,67 \\
\hline 2 & Over Finance - Terdeteksi & 7,69 & 7,14 & 6,67 & 8,33 \\
\hline 3 & Interest - Komersial & 10,77 & 11,43 & 8,00 & 10,00 \\
\hline 4 & Interest - Subisidi & 9,23 & 8,57 & 12,00 & 10,00 \\
\hline 5 & Experience - Uji Coba & 9,23 & 11,43 & 9,33 & 13,33 \\
\hline 6 & Experience - Gagal Ekspansi & 10,77 & 8,57 & 10,67 & 6,67 \\
\hline 7 & Managerial - Rendah & 10,77 & 14,29 & 14,67 & 15,00 \\
\hline 8 & Managerial - Matang & 9,23 & 5,71 & 5,33 & 5,00 \\
\hline 9 & Leadership - Rendah & 12,31 & 12,86 & 12,00 & 11,67 \\
\hline 10 & Leadership - Matang & 7,69 & 7,14 & 8,00 & 8,33 \\
\hline
\end{tabular}

Kelompok usaha 1, penyebab utama kebangkrutan adalah over financing yang tidak terdeteksi dan leadership yang rendah keduanya memiliki bobot masing-masing $12,31 \%$. Kemudian penyebab tertinggi kedua adalah suku bunga komersial, gagal ekspansi dan manajerial yang rendah. Masing-masing memiliki bobot $10,77 \%$. Kelompok usaha 2, penyebab utama tertinggi kebangkrutan adalah manajerial atau tata kelola pengurusan perusahaan yang lemah (bobot 14,29\%) dan diikuti oleh leadership yang rendah $12,86 \%$. Kelompok usaha 3, penyebab kebangkrutan tertinggi adalah manajerial yang rendah (bobot 14,67\%) dan tidak terdeteksinya over financing akibat kredit yang tidak terdeteksi pada saat analisa kredit dilakukan dengan bobot 13,33\%. Kelompok usaha 4, kebangkrutan terutama disebabkan oleh manajerial rendah $(15 \%)$ dan kegagalan usaha karena bersifat uji coba $(13,33 \%)$.
Dari keempat kelompok usaha selalu ada faktor manajerial yang lemah sebagai penyebab utama kebangkrutan. Faktor lain yang menjadi penyebab kebangkrutan tertinggi adalah over financing, leadership yang lemah, suku bunga komersial, gagal ekspansi, kegagalan usaha karena uji coba.

UKM memiliki masalah utama terkait kemampuan tata kelola perusahaan, yaitu kegiatan administrasi termasuk pembukuan dan pelaporan keuangan. Kelemahan tata kelola juga termasuk ketidak mampuan UKM mengendalikan semua proses usaha.

Penyebab dominan lain dari keempat kelompok usaha adalah tidak terdeteksinya kredit yang telah diterima UKM pada saat analisa pembiayaan dilakukan. Hal ini terjadi karena tidak semua kredit mikro terdeteksi dalam SID Bank Indonesia. Banyak kreditor non formal yang berada di sekitar pengusaha UKM menyulitkan proses analisa apakah 
calon debitur sudah maksimum dalam perhituingan repayment capasity. Tidak terdeteksinya kredit, menyebabkan SDM lembaga keuangan gagal menyajikan angka repayment capacity yang sesuai dengan kenyataan.

Leadership yang lemah adalah kemampuan debitur UKM dalam menerapkan strategi bisnis dan rencana ke depan. Kemampuan mengendalikan semua proses tata kelola adalah indikasi kelemahan manajerial. Jika leadership terkait visi misi dan strategi termasuk pemecahan masalah dan kemampuan solusi. Manajerial terkait administratif, pembukuan dan proses menjalankan usaha berdasarkan fungsi-fungsi bisnis.

Suku bunga komersial diambil oleh UKM karena situasi yang sulit, tidak mempunyai akses ke tempat lain, atau karena asimetri informasi. Rate yang tinggi tidak diketahui oleh UKM. Namun dalam pelaksanaannya, UKM tidak mampu menanggung beban bunga yang tinggi selama kredit berlangsung.

Gagal ekspansi karena kemampuan yang terbatas dalam mengelola usaha. Tidak siap dengan jaringan yang baru. Ketidaktahuan informasi sehingga tertipu. Menjalankan usaha dengan skala Rp.100 juta tidak sama dengan mengelola usaha Rp.1 Milyar.

Uji coba usaha yang gagal lebih disebabkan karena aturan pengalaman 2 tahun usaha namun pembuktian dari instansi setempat kurang sesuai dengan kenyataan. Hanya berdasarkan klaim sepihak atau pengakuan dari calon debitur. Tidak memiliki data kapan usaha pertama kali dilakukan karena tidak ada kewajiban bagi UKM untuk melakukan itu.

\section{Kesalahan Memahami Karakteristik Debitur}

Dari proses komunikasi dan pembinaan debitur, SDM lembaga keuangan yang menjadi obyek penelitian kurang memahami karakteristik debitur apakah Dominance, Influence, Steadiness, Compliance, sehingga potensi salah treatmen dan pembinaan saat kredit awal diinisiasi dan paska bermasalah atau NPL, menjadi tinggi. Namun demikian, kesalahan memahami karakteristik ini hanya merupakan faktor pendukung penyebab kebangkrutan. Faktor utama yang dikemukakan pada bahasan sebelumnya adalah penyebab utama yang dominan dijumpai dari debitur yang bangkrut.

\section{Asimetri Informasi dari UKM}

Paradigma UKM layak memang tidak mudah. Selain informasi yang terbatas, juga disebabkan oleh persepsi UKM yang tidak valid terhadap kredit sehingga proses keputusan mencari pembiayaan kredit juga didasari perhitungan yang kurang tepat. Asimetri informasi ini, pada mulanya positif terhadap kinerja Lembaga keuangan karena jumlah pertumbuhan kredit dan pertumbuhan NOA penerima kredit menjadi kinerja positif bank. Namun dalam perjalanannya, asimetri informasi ini berbalik menjadi hal negatif bagi bank, yaitu timbulnya kredit bermsalah yang buruk dari komponen NPL dan biaya cadangan kerugian piutang (CKPN).

Berikut adalah tanggapan UKM terhadap beberapa hal terkait kredit:

\begin{tabular}{|l|l|c|}
\hline 1 & Proses kredit harus cepat tanpa berbelit lebih penting daripada suku bunga. \\
\hline \multirow{2}{*}{} & Sangat setuju & 27 \\
& Setuju & 13 \\
& Biasa Saja & 8 \\
& Tidak setuju & 6 \\
& Alasan sangat setuju: & \\
\hline
\end{tabular}




\begin{tabular}{|l|l|c|}
\hline & kebutuhan mendesak, yang penting cepat & \\
\hline 2 & Staf bank yang ramah adalah penting untuk meyakinkan & ambil kredit. \\
\hline \multirow{3}{*}{} & Sangat mendukung & 35 \\
& Mendukung & 10 \\
& Biasa saja & 9 \\
& Tidak mendukung & 0 \\
& Alasan sangat mendukung: \\
\cline { 2 - 3 } & Takut ditipu, tidak mengerti, malu & \\
\hline 3 & Melengkapi dokumen untuk data persyaratan kredit secara lengkap \\
\hline \multirow{3}{*}{} & Keberatan & 37 \\
& Tidak keberatan & \\
& Alasan keberatan: & \\
\cline { 2 - 2 } & Kebutuhan mendesak, biaya, ingin dibantu. & \\
\hline
\end{tabular}

Adanya asimetri informasi di atas, maka sikap UKM terhadap kredit yang penting cepat dan dilayani dengan baik serta persyaratan mudah. Dengan alasan seperti ini UKM di atas akhirnya terjerat dengan tingkat suku bunga yang tinggi dan berbagai biaya. Tipe UKM dengan asimetri informasi ini berakibat memudahkan bank untuk memberi kredit karena tidak menawar bunga. Dengan rate produk lembaga keuangan yang tinggi, dengan kondisi debitur tidak elastis terhadap bunga, akan menjadi incaran targetnya. Apabila hal ini disertai dengan integritas yang rendah dari SDM, maka berbagai faktor penyebab di atas dapat dimodifikasi atau rekayasa. Hal ini memungkinkan karena terbatasnya cross checking dan data formal yang terbatas. Selain itu, jangkauan pengendalian SDM oleh atasan dan atasan langsung terbatas dibandingkan dengan jumlah UKM yang dilayani.

\section{Penutup}

\subsection{Simpulan}

Lembaga keuangan yang tidak memiliki SDM dengan skill atau competency cukup baik akan cenderung mudah keliru dalam memahami dan menentukan UKM layak. Kesalahan lebih diperparah jika SDM juga memiliki integritas yang rendah. SDM yang memiliki kompetensi dan integritas rendah akan mengakibatkan kontra produktif terhadap tujuan atau misi pemberdayaan UKM karena kredit yang diberikan tidak tepat. Kondisi SDM yang rendah juga akan semakin dipicu pemburukannya jika target yang diberikan oleh perusahaan untuk menyalurkan kredit diluar kemampuan atau target yang tidak masuk akal.

Pemberian kredit oleh lembaga penyalur kredit yang tidak tepat akan menyebabkan kesulitan bagi UKM dan kebangkrutan. Bangkrutnya UKM juga akan menyebabkan kerugian bagi lembaga penyalur kredit dengan indikator NPL yang semakin meningkat. Faktor penyebab kebangkrutan harus diminimalkan dengan design atau metode analisis kredit yang lebih komprehensif termasuk kriteria produk lembaga keuangan dan kriteria UKM yang sanggup menunaikan kewajiban.

\subsection{Saran}

1. Produk kredit lembaga keuangan disusun dan ditawarkan dengan kehati-hatian. Lembaga keuangan pelayan kredit mikro harus siap dengan margin kecil namun skala luas

2. Pengawasan otoritas diperlukan secara lebih komprehensif terhadap lembaga keuangan penyalur kredit 
mikro. Kredit mikro bukan sarana untuk mendatangkan keuntungan skala komersial tapi pemberdayaan, kemitraan dan nasabah yang disikapi dengan keterbukaan.

3. Training and development SDM untuk meningkatkan skill mengasah integritas sehingga lebih valid dalam analisis kredit dan minimalkan kesalahan di atas.

4. Technical assistance satu paket dengan pembiayaan. Memimasi kelemahan tata

kelaola/administrasi dan leadership pengusaha mikro sehingga dapat lebih mengoptimalkan kredit yang diterima.

\section{Referensi}

Prof.DR.H.Veithzal Rivai, Andria P, Arifiandy, Credit Management Handbook, Manajemen Perkreditan Cara Mudah Menganalis Kredit, PT.RajaGrafindo Perkasa, Jakarta, Juli 2013, Edisi Revisi.

Stephen A. Ross, Randolph, Jeffrey, Joseph, Ruth, Helen, Corporate Finance, Asia Global Edition, McGrawHill Education, 2015.

N.Lapoliwa, Akuntansi Perbankan, Institut Bankir Indonesia, Edisi kelima 2000.

I Gusti Ayu, Gede, Ni Luh, Akuntansi Perbankan, Teori dan Soal Latihan, Graha Ilmu, 2014.

Jopie Jusuf, Panduan Dasar Untuk Account Officer, Intermedia Jakarta, 2000. 